
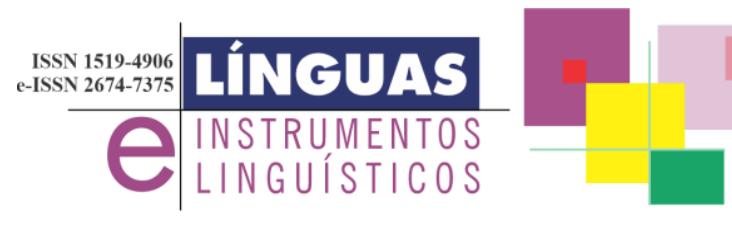

DOI: $10.20396 /$ lil.v24i47.8660936

\title{
A crise pandêmica e a noção de empreendedorismo no discurso publicitário
}

\section{The pandemic crisis and the notion of entrepreneurship in the advertising discourse}

\author{
Edjane Gomes de Assis*
}

UFPB

Resumo: Com base na Análise do Discurso de linha francesa, na esteira de teóricos como Pêcheux, Foucault e Courtine, o artigo objetiva investigar a noção de empreendedorismo materializada na campanha publicitária "Aguente firme para reinventar o futuro", do Banco Bradesco. Sabemos que a mídia, através do dizer publicitário, promove sentidos. E nesta crise sanitária com consequências no setor econômico, o discurso aparece com o objetivo de dialogar diretamente com um público - o empreendedor. Observamos que a articulação de elementos constituídos nesta peça publicitária emoldura os efeitos que a empresa propõe recriar na instância social. Tais elementos funcionam como dispositivos disciplinares para gerar lucro. Há uma proposta de recriar um sentido de resiliência, companheirismo e motivação, a fim de que este empreendedor sinta-se representado por uma empresa que pensa no futuro. Com estas tecnologias disciplinares que se aproximam de um poder pastoral, a empresa propõe docilizar os sujeitos e torná-los corpos úteis.

Palavras-chave: Discurso, Bradesco, Empreendedorismo.

Abstract: Based on the Analysis of the French Line Discourse, in the wake of theorists Pêcheux, Foucault and Courtine, the article aims to 
investigate the notion of entrepreneurship materialized in the advertising campaign, "Steady to reinvent the future", of Banco Bradesco. We know that the media, through advertising, promotes meanings. And in this health crisis with consequences in the economic sector, the discourse appears with the objective of dialoguing directly with the public - the entrepreneur. We observed that the articulation of elements constituted in this advertising piece, frame the effects that the company proposes to recreate in the social instance. Such elements act as disciplinary devices to generate profit. There is a proposal to recreate a sense of resilience, companionship and motivation, so that this entrepreneur feels represented by a company that thinks about the future. With these disciplinary technologies that approach a pastoral power, the company proposes to docilize the subjects and make them useful bodies.

Keywords: Discurso, Bradesco, Entrepreneurship.

\section{Discussões iniciais}

Desde o início de 2020, após o primeiro óbito comprovado por coronavírus, o Brasil vem enfrentando sérios problemas que atingiram não apenas a área da saúde como também outros setores da sociedade. A covid-19 é uma doença de grande complexidade que tem intrigado a comunidade científica e está na fase de testes voltados para a fabricação de uma vacina. Em 19 de agosto de 2020 o Brasil conta com 110.171 óbitos registrados e 3.418.306 diagnósticos de Covid-19¹ . Os números preocupam pela velocidade de agravamento da pandemia com aumento do número de óbito e contaminados em poucos meses - o que tem obrigado o poder público a fazer um ajuste em suas agendas, na perspectiva de tentar dirimir os danos que vêm se multiplicando a cada dia.

Há uma frase atribuída ao ex-senador americano Hiram Johnson em que se afirma que "numa guerra, a primeira vítima é a verdade". Percebemos que além do crescente número de óbitos e contaminação, a pandemia ressuscitou antigos conflitos que até então acreditávamos que já havíamos superado: desconfiança na ciência, dissonâncias político-partidárias, reafirmação de velhos mitos sobre 
curas milagrosas. Dentre tantas efervescências dominantes neste ambiente caótico, surgiram posicionamentos que trataram a saúde e economia como polos antagônicos, quando sabemos que as duas áreas se coadunam. Um governo que trata da saúde, a rigor, deve cuidar também da economia do país. Vemos, portanto, que o discurso, em suas mais diferentes modalidades, é o espaço encontrado pelas instâncias ideológicas para (in)formar a sociedade. Dentre tantos discursos que apareceram neste emaranhado de significações, temos o discurso publicitário, que se metamorfoseia a partir de vários lugares, afirmando e cristalizando valores.

Como vivemos em um ambiente capitalista, o discurso publicitário, sobretudo neste cenário de pandemia, passa a imprimir valores que dialoguem diretamente com um consumidor em potencial. Foi o que fizeram os bancos, mais precisamente, os que se circunscrevem no setor privado. De modo paradoxal, as perdas econômicas impulsionaram o mercado publicitário a criar peças que aparecem com discursos voltados para a instauração de uma positividade e legitimidade. Constrói-se uma atmosfera de confiança e proximidade com o cliente, mas sempre com um teor apelativo que utiliza a dramaticidade como uma estratégia produtiva para angariar mais capital - o objetivo é atingir mentes e corações daqueles que observam um futuro com perspectivas negativas.

Pesquisas $^{2}$ realizadas por economistas e investidores no setor empresarial apontam um número significativo de empresas que decretaram falência por conta da pandemia do coronavírus. Muitas tiveram que demitir funcionários e outras não conseguiram linhas de crédito para sobreviver neste momento de crise. É neste momento, sempre em sintonia com a realidade social, que a mídia, enquanto um lugar de verdade por atuar numa instância de poder, articula um discurso emoldurado de efeitos que visam estabelecer um contato mais próximo com o público, e, assim, obter lucro. A técnica de refinamento da informação proporcionada pelas redes tecnológicas típicas deste século XXI contribui para promover efeitos de sentido e ratificar valores defendidos no ambiente empresarial. É através do discurso que as relações sociais acontecem e as subjetividades ganham novos contornos.

Com base nestas premissas, o Banco Bradesco S.A veiculou no mês de maio de 2020 uma campanha que contém todos os elementos de uma narrativa que dialoga diretamente com o contexto atual. Tais elementos 
configuram elementos de poder que disciplinam o olhar do leitor/cliente.

A partir destes aspectos observados preliminarmente o artigo objetiva analisar os efeitos de sentido voltados para a noção de empreendedorismo articulados nesta propaganda do Bradesco que foi veiculada no YouTube, bem como em outras plataformas midiáticas. Com base na Análise do Discurso de linha francesa (AD), na esteira de teóricos como Pêcheux, Foucault e Courtine, analisamos como o discurso da campanha reproduz no imaginário social, um aspecto de acolhimento através de todo um jogo de relações em que se promove efeitos de positividade da empresa perante o público.

Nosso percurso está sistematizado da seguinte forma: No primeiro momento tratamos de apresentar algumas categorias pertinentes para nossa análise: Discurso, Poder e disciplina. Mais adiante, observamos como se configura o discurso publicitário ao articular mecanismos disciplinares. E no tópico de análise, investigamos como foram utilizadas as tecnologias de poder para ratificar a noção de empreendedorismo que dialogam com as premissas defendidas pelo mercado financeiro. E assim, a empresa se mantém firme no mercado apesar de uma das maiores crises vivenciadas na atualidade.

\section{Discurso, poder, disciplina}

A década de sessenta compreendeu uma época de profundas transformações em vários espaços sociais. São emblemáticas as lutas pelos direitos das minorias que almejavam a igualdade de oportunidades e tantos outros direitos negados ao longo do tempo. Se destaca nestas práticas de resistência a reivindicação de países pela independência, sobretudo aqueles que estavam debaixo de domínios autoritários por um largo período da história.

No campo intelectual, destacamos mudanças significativas nos estudos linguísticos com a chamada "virada pragmática", em que se evidencia uma releitura do Estruturalismo e a focalização não apenas dos aspectos morfossintáticos das sentenças, mas o sujeito da enunciação e seus modos de significação. Com tais propostas, surgem teorias como: a Linguística Textual, a Sociolinguística, a Etnolinguística, bem como as diversas correntes teóricas do discurso. Cada olhar, por seu turno, cultiva alguns aspectos de similitude: 
considerar que a análise incide também em aspectos extralinguísticos e observar que a língua é dinâmica e reproduz as práticas culturais.

Sobre as teorias discursivas, destacamos a Análise do Discurso de linha francesa que aparece em 1969 trazendo todo um arcabouço de análise que visa estabelecer uma série de rupturas com os postulados de Saussure, tais como: a) ruptura com a concepção de língua enquanto objeto fechado, acabado. b) Ruptura com a noção de sujeito da estrutura em detrimento de um sujeito discursivo; c) ruptura com a noção de texto apenas como unidade de sentido com projeção para elementos extralinguísticos.

Em Análise Automática do Discurso (1969), Michel Pêcheux, o fundador da Análise do Discurso, aponta para a necessidade de uma maior articulação entre língua e ideologia. Apresenta as bases para uma linha de interpretação de textos para além de sua materialidade. Aprofunda a investigação para a categoria do discurso, ou seja, a linguagem em curso, na compreensão de como os sentidos se configuram na trama discursiva.

Conforme Pêcheux (1997, p.63): “É impossível analisar um discurso como um texto (...) é necessário referi-lo ao conjunto de discursos possíveis, a partir de um estado definido das condições de produção." A afirmação do teórico revela alguns sinais de distanciamento das ideias postuladas na Linguística estrutural, na centralidade do texto como uma extensão da frase ou análise das sentenças.

A investigação sobre a complexidade social, sobretudo nos movimentos ideológicos que ocupavam os debates e reflexões pós "maio de 68" na França, atinge outros espaços e traça um novo modelo de análise linguística. Assim, é imprescindível observar as condições em que os discursos são proferidos, em como os dizeres promovem efeitos de sentido. Para Pêcheux (1997, p.77):

Um discurso é sempre pronunciado a partir de condições de produção dadas. (...) Se prosseguirmos com a análise do discurso político - que serve apenas de representante exemplar de diversos tipos de processos discursivos - veremos que (...) ele deve ser remetido às relações de sentido nas quais é produzido: assim, tal discurso 
remete a tal outro. (...) Em outros termos, o processo discursivo não tem, de direito, início: o discurso se conjuga sempre sobre um discurso prévio. (Grifos do autor).

Conforme observa o teórico, não há um discurso original. Há sempre ressonâncias, um dizer prévio. O que fazemos, pois, é repetir enunciados de outras formas, com outras nuances, pois é no e pelo discurso que os sujeitos (re)afirmam suas identidades e promovem efeitos de sentido. Michel Pêcheux, a partir de seu alinhamento com as ideias do marxismo, encontra nos estudos linguísticos uma forma de analisar práticas de sua contemporaneidade que não se esgotam mais na palavra escrita, mas deve ser considerada a historicidade do texto.

$\mathrm{O}$ analista do discurso deve levar em conta as condições em que os enunciados são produzidos, o lugar e posição do sujeito em situação discursiva. Não há um enunciado neutro, nem original. Há sempre um já dito, um pré-construído, há deslizamentos que ressurgem como um "novo" dizer. E só é possível analisá-lo, a partir da materialidade discursiva.

É importante destacar que o discurso não compreende tão somente um texto verbal, mas uma imagem, um gesto, uma cor, um som, um silêncio localizado. A análise focaliza as circunstâncias em que são proferidos estes discursos. Por mais profundo que se tente chegar na compreensão e interpretação de um determinado discurso, sempre há mais para ser dito, sempre há mais para ser observado.

Assim, a Análise do Discurso se configura na tríade LinguísticaHistória-Psicanálise. Sobre a Linguística, a AD estabelece uma releitura de Saussure através de Pêcheux; os conhecimentos da História, mais especificamente do materialismo histórico, a AD fazem uma releitura de Marx através de Althusser; e no campo da Psicanálise, é feita a releitura de Freud através de Lacan. São princípios que ancoram as bases de uma disciplina de entremeio.

A mobilização de outros domínios do saber evidencia a necessidade de uma pluralização do conhecimento que revela as condições dadas e postas naquela conjuntura da década de sessenta. A Linguística passa por um redimensionamento, mas sem esquecer das ideias que já estavam postuladas com Saussure - aquele que abriu o caminho para novas possibilidades de análise da língua e suas várias manifestações. 
Além de Michel Pêcheux não podemos deixar de evidenciar outro teórico de significativa relevância - Michel Foucault. Embora advindos de uma mesma escola francesa há algumas diferenças teóricas que os distanciaram, sobretudo quanto ao tratamento dado à concepção de ideologia.

O teórico problematiza a noção de poder de modo distinto da concepção que se defendia no cerne da Análise do Discurso, em que o poder estava ligado diretamente ao Estado. Contrariamente, Foucault vai defender que o poder circula. A questão pontuada compreende, pois, em não analisar o poder como algo estanque e dicotômica - uma estrita relação entre o bem e o mal. Concebendo o discurso como um terreno fértil para a germinação do poder, o filósofo encontra nesta materialidade o terreno em que as subjetividades afloram e propiciam a resistência.

Para Foucault, "o discurso não é simplesmente aquilo que traduz as lutas ou os sistemas de dominação, mas aquilo por que, pelo que se luta, e poder do qual nos queremos apoderar." (FOUCAULT, 2000, p. 10). O pensamento do filósofo compreende a relação de forças constituídas no discurso, o espaço de dominação. Visto de forma ampla, consideramos que o discurso se metamorfoseia num jogo de universos simbólicos. Portanto, a imagem de um punho erguido, por exemplo, configura um discurso porque tem uma história e ratifica uma memória por traduzir a luta pela igualdade de direitos, sobretudo a resistência contra posicionamentos autoritários e antidemocráticos. Quem nos diz isso é a história, são os lugares em que uma determinada imagem, que é um discurso, promoveu sentido.

O punho fechado e erguido dentro de uma conjuntura dada ficou, portanto, ratificado na história como instrumento de resistência. Tal aspecto mostra que o sujeito não pode ser visto como totalmente assujeitado (dominado, alienado) pelo Estado. Mas se utiliza do discurso e de um lugar e posição para exercer poder. A análise sobre a resistência, que também configura poder, resultou no reposicionamento de Pêcheux e uma aproximação com as ideias defendidas por seu contemporâneo Foucault.

Vemos que o poder e seus dispositivos foram amplamente estudados por Foucault. Mesmo tendo como premissa estudar o sujeito, o teórico vê a impossibilidade de estudá-lo sem que se considere as relações disciplinares que o atravessam. Surge então, a necessidade de investigar 
o poder dentro de uma microfísica, um dispositivo dinâmico e cíclico. Tudo está na ordem das leis, dispositivos de poder: a definição da loucura, a aplicação das punições, a seleção dos acontecimentos históricos, a ideia de verdade, a formação dos saberes. São apenas alguns dos aspectos que só são definidos e validados porque são arquitetados no jogo das leis, cujo papel é disciplinar os sujeitos e os transformar em corpos dóceis, mas capazes de resistir.

Através do fazer genealógico inspirado no método de Nietsche, Foucault problematiza os aspectos implicados na formação dos saberes. Para tanto, analisa as práticas discursivas do século XVIII, quando questiona como o conhecimento pautado nas instâncias de poder (medicina, Direito, Educação, entre outras), é utilizado para a geração de forças que disciplinam, vigiam e punem os sujeitos. Contudo, mesmo de modo de sutil, há de considerar que sempre houve resistência. A própria necessidade de punição era resultante de uma ação.

Assim, por mais que existam dispositivos prontos para disciplinar os sujeitos, as condições de resistências também estão postas e podem ser acionadas sempre que for necessário. $\mathrm{O}$ que se entende, portanto, por disciplina? Foucault $(2005$, p. 105) responde: "É uma técnica de exercício de poder que foi, não inteiramente inventada, mas elaborada em seus princípios fundamentais durante o século XVIII."

Até a primeira metade do século XVIII, a sociedade conviveu com normas disciplinares que objetivavam disciplinar o corpo dos indivíduos. A punição, feita em praça pública e através de decretos estabelecidos, atinge o corpo que serve de instrumento para ratificar o poder disciplinar. A partir da segunda metade do século XVIII e caminhando para a revolução industrial do século XIX, os modos disciplinares passam por uma transformação. As disciplinas, neste novo momento, atuam na sociedade de controle por meio de decretos, através de um construto de normas e dispositivos. As punições antes vistas em público, passam a ser executadas no âmbito privado.

Como exemplificação desta sociedade de controle, o teórico utiliza a metáfora do panóptico - o olho que tudo vê - um projeto arquitetônico feito para o sistema prisional, de modo que cada cela é direcionada para uma torre central. E tal torre vigia todas as celas. A função deste controle é tornar corpos dóceis e úteis para o trabalho. Assim funciona também a sociedade. Somos vigiados, disciplinados, mas também vigiamos, também disciplinamos. 
Discurso, poder e disciplina são, deste modo, conceitos indissociáveis. E por fazerem parte de nossa prática social, são imperceptíveis em nossas relações cotidianas. As categorias de análise já mostram que a preocupação sobre os eventos linguísticos deve ser explicada em sua exterioridade, nas condições de produção, na historicidade do dizer.

No discurso midiático estão configurados elementos utilizados como modos de disciplinarização. Há uma luta constante e infinita para conquistar os sujeitos através de uma valorização que se denominou de mobilização da opinião pública. E quando o que está em jogo é uma crise sanitária com consequências em vários outros setores da sociedade, a comunicação, que aqui traduzimos como processo de discursivização, recebe um maior cuidado tais como: abundância de recursos imagéticos, utilização palavras de efeito para produzir sentido. É o que ocorre no discurso instaurado em uma peça publicitária. Entendemos que o discurso publicitário exerce poder por ocupar um lugar de verdade e por conduzir o olhar dos sujeitos para assimilação de verdades, sobretudo num contexto pandêmico em que as incertezas se aprofundam. Problematizamos tais aspectos no próximo tópico.

\section{O discurso publicitário e seus efeitos de sentido}

Enquanto produtor de "verdade" e sempre se reafirmando na atualidade, o discurso publicitário compreende um lugar propício para a sedimentação de dizeres e valores que atingem os sujeitos em suas mais diferentes atividades. A linguagem utilizada em uma peça publicitária deve ser objetiva, direta e clara, de modo que a mensagem alcance diretamente, e de modo instantâneo, as mentes e corações dos potenciais consumidores. Há uma reelaboração de signos, ícones que dialogam com os enunciados verbais. Um dos princípios fundantes no discurso publicitário é criar uma necessidade de consumo. Os produtos aparecem como indispensáveis para a vida dos indivíduos para que este alcance uma felicidade plena.

Há, portanto, um filtro da realidade utilizado para mobilizar o imaginário social. Sobre a forma como a mídia refrata o acontecimento, ou seja, a realidade, o teórico Patrick Charaudeau (2006) faz a seguinte observação: $O$ acontecimento nunca é transmitido à instância de recepção em seu estado bruto: para sua significação, depende do olhar 
que se estende sobre ele, olhar de um sujeito que o integra num sistema de pensamento e, assim fazendo, o torna inteligível. (CHARAUDEAU, 2006, p. 95).

O que vemos diante das lentes midiáticas, nunca é a realidade concreta, mas os efeitos de uma realidade. Há uma manipulação (manuseio) dos fatos com uma estética funcional capaz de produzir sentido. No discurso publicitário, os sanduíches sempre parecem mais apetitosos, as roupas estão sempre com cortes impecáveis, os corpos são mais exuberantes e estão em conformidade com as convenções da moda. E o que dizer dos dentes? Estes são sempre mais brancos.

As estratégias utilizadas no dizer propagandístico tem suas raízes nos estudos clássicos, mais especificamente, na Retórica - a arte de bem falar, argumentar. Neste sentido, há uma relação de poder demarcada pelos papéis que cada sujeito desempenha: De um lado, temos a voz da empresa em posição de liderança (o poder da palavra) capaz de legitimar uma verdade. Do outro lado, temos o sujeito consumidor que embora também ocupe um lugar social e tenha uma historicidade, precisa ser conduzido por outros sujeitos que ocupam outros lugares sociais. Mas este sujeito (potencial consumidor) pode também se tornar um adversário e refutar as ideias vendidas por uma determinada empresa.

Cria-se um mundo perfeito para sujeitos que buscam uma felicidade mesmo que ela custe caro. As mensagens, como são articuladas quase que de modo cirúrgico, cumprem sua função. Não é à toa que algumas peças publicitárias e seus slogans ficaram imortalizados no país. Rememoremos alguns: "Não esqueça a minha Caloi", "Compre batom", "O primeiro Valisére a gente nunca esquece", "Bombril tem mil e uma utilidades". Se ainda hoje retomamos tais slogans, é porque vivemos num universo de múltiplas semioses que passaram a fazer parte de nossa história.

Uma boa propaganda tem a capacidade de eleger ou derrubar líderes. Foi por meio de uma sofisticada campanha publicitária, aliada aos anseios de uma sociedade que ainda padecia das consequências da Primeira Guerra Mundial, que Joseph Goebbels abriu o caminho para que o ditador Adolf Hitler colocasse em ação seu projeto eugenista e genocida. A mídia, através do discurso publicitário, compreende uma instância ideológica que atua com dispositivos de alto poder destrutivo 
quando utilizada em mãos erradas. Vale destacar algumas características do discurso publicitário:

a) Faz parte de nossas práticas cotidianas;

b) Se constitui através das várias necessidades do indivíduo, desde aspectos materiais aos sentimentais.

c) Utiliza uma linguagem clara e objetiva para dialogar diretamente com o público.

d) Estabelece uma relação de proximidade do público com o objeto que será consumido.

e) Pode reproduzir preconceitos e estereótipos.

f) Cria uma necessidade de consumo.

g) Induz o público a crer que ele é o protagonista de suas realizações.

h) Articula um efeito de igualdade e acessibilidade quando defende que qualquer indivíduo é capaz de comprar determinado produto.

i) Fabrica um discurso de prestação de serviço e responsabilidade social.

São alguns princípios que nos chegam de modo imperceptível devido ao dinamismo e efemeridade das práticas cotidianas porque se estabelece de modo sutil, um disciplinamento dos corpos, a fim de torná-los úteis para o consumo. Mas estes modos disciplinares não aparecem de modo incisivo, mas sutil e com efeitos de uma positividade e bem estar. É assim que o poder se sustenta e se mantém na sociedade, conforme bem observa Foucault $(2005$, p.8): "O que faz com que o poder se mantenha e que seja aceito é simplesmente que ele não pesa só como uma força que diz não, mas que de fato ele permeia, produz coisas, induz ao prazer, forma saber, produz discurso."

Os discursos difundidos pela publicidade vão se ajustando às demandas sociais, porque o que deve ser priorizada é a sensação de acolhimento e identificação do consumidor com determinada marca. Assim, não é mais positivo para a imagem de uma empresa, a reverberação de um discurso misógino e racista. Como exemplo, podemos citar o reposicionamento da marca Skol conhecida pelo slogan "A cerveja que desce redondo" em alusão às formas do corpo de uma mulher. Nos dias atuais, a marca incorpora um discurso da diversidade e outras bandeiras defendidas por grupos organizados, o que produz um efeito de positividade, e, a rigor, potencializa o consumo e gera lucro. 
As mudanças discursivas utilizadas na publicidade se devem aos movimentos de resistência exercidos pela sociedade. Mostra, ainda, como os mecanismos de vigilância nos submetem e nos disciplinarizam. Ao mesmo tempo em que a mídia vigia, também é vigiada por qualquer indivíduo que pode se sentir agredido e não representado neste jogo simbólico fabricado em uma peça publicitária.

Para tanto, no Brasil, temo o CONAR (Conselho Nacional de Autoregulamentação Publicitária) - o que reflete que nossas práticas são conduzidas pela ordem das leis ${ }^{3}$. Isto nos faz ver e entrever que não podemos dizer tudo o que queremos em qualquer momento, em qualquer lugar, de qualquer forma. Contudo, haverá sempre sujeitos "livres" que ocupam lugares outros, com histórias outras - é o que traduz a relação de forças tão amplamente estudada por Foucault.

Como vemos, o espaço público é um terreno fértil para germinação de valores que se metamorfoseiam conforme as mudanças das conjunturas político-sociais. E neste contexto de pandemia, as peças publicitárias receberam um tratamento cirúrgico para atingir de modo fulminante o outro - o sujeito consumidor. E quando se trata da saúde financeira dos brasileiros, ou dos microempreendedores, entram em linha de frente empresas preocupadas em não aprofundar a crise, sobretudo quando esta empresa configura um banco privado como o Bradesco S.A. diante da campanha "Aguente firme para reinventar o futuro", conforme analisamos no próximo tópico.

\section{4. "Aguente firme para reinventar o futuro": O Bradesco em (dis)curso na pandemia de coronavírus}

Nem o indivíduo mais pessimista poderia prever a tão devastadora crise sanitária que vivemos desde o final de 2019, e no Brasil, desde o terceiro mês de 2020. Além da área da saúde, a pandemia atingiu outras áreas, como a econômica. Analistas do mercado financeiro e representantes empresariais vêm contabilizando as perdas de capital tanto de pessoas físicas como jurídicas. Esta discussão entre saúde e economia foi posta em jogo e, de certo modo, apareceu envolta de uma intensa politização. De um lado, surge o discurso científico que, seguindo protocolos internacionais, prescreve o isolamento social e o fechamento temporário de estabelecimentos considerados não essenciais, para evitar aglomerações. Em outro lugar, aparecem 
empresários, que insatisfeitos com os decretos e protocolos, tentam discutir uma forma mais rápida para voltar à vida produtiva conforme as diretrizes do mercado capitalista.

No calor das discussões que movimentaram o cenário nacional, as propagandas de empresas financeiras que ocupam o setor privado passam a atuar com um discurso de compromisso com a sociedade, mas com o objetivo de gerar lucro e fortalecimento das demandas neoliberais. O neoliberalismo é uma política econômica que defende a menor intervenção possível do Estado. Considera que o setor privado deve ter primazia nas agendas econômicas.

O discurso que fundamenta o conceito de "empreendedorismo" foi a fórmula encontrada pelo Bradesco na campanha "Aguente firme para reinventar o futuro" veiculada no YouTube ${ }^{4}$, bem como em outros espaços midiatizados. Sabemos que o Banco Bradesco S.A. é uma empresa privada que atua no país desde 1943, ou seja, ainda antes do final da Segunda Guerra Mundial.

A empresa possui alguns projetos de incentivo cultural/educacional - o que reflete o princípio da responsabilidade social que funciona como uma estratégia de marketing e instaura um efeito de positividade e credibilidade na sociedade. E nestes tempos de pandemia, o Bradesco tem presença marcante em eventos sociais e se uniu ao grupo de outras empresas privadas que, através de ações solidárias, investiram em estratégias de combate e diminuição dos danos provocados pelo coronavírus.

Paradoxalmente, nas tragédias, como nesta guerra atual, ganham destaque os sujeitos (seja pessoa física ou jurídica) que conseguem implementar medidas estratégicas contra o adversário. No contexto de pandemia, este inimigo é ainda mais letal por ser invisível, mas com potencial de destruição incalculável.

Estudo o discurso publicitário é considerar que vivemos em uma sociedade de controle (conforme a perspectiva de Foucault acerca da analogia ao panóptico de Jeremy Bentham). Assim, cada enunciado proferido, e até omitido, passa por um intenso e constante processo de vigilância, sobretudo por vivermos em um século marcado pelas novas tecnologias, e, consequentemente pelas múltiplas formas de difusão da informação. Ironicamente, a difícil realidade que tem se apresentado no país nestes últimos meses propicia discursos capazes de atingir 
diretamente sujeitos que se encontram em um momento de fragilidade e profunda vulnerabilidade.

Uma pesquisa $^{5}$ divulgada em 18 de agosto de 2020 pela Organização Pan-americana da Saúde (OPAS) informa que a pandemia de covid-19 causou uma crise de saúde mental sem precedentes em todo o continente americano. Depressão, ansiedade e estresse são alguns dos problemas que acometem a sociedade, revelando que o vírus produz outros efeitos colaterais, além dos sintomas já conhecidos e estudados.

A insegurança no futuro, o medo de perder familiares ou a própria vida, dominaram nossa prática cotidiana desde a chegada do vírus em território nacional, atingindo de forma ainda mais fulminante a população menos favorecida, mas também os sujeitos que guardaram suas economias para abrir uma empresa ou começar um novo negócio e se tornar autônomo, ser seu próprio chefe.

Alguns especialistas observam que após esta crise de largas proporções, os países, sobretudo os que sempre apresentaram altos índices de desigualdade social, ainda vão passar por um longo processo de instabilidade, tendo em vista as grandes perdas sofridas em vários setores, principalmente o setor econômico. Nos últimos meses, assistimos a histórias de empresas (pequenos restaurantes, lojas de produtos naturais, barbearias, por exemplo), com raízes já consolidadas no mercado nacional e muitas que cultivam heranças familiares, que fecharam suas portas por não terem mais condições de manter o funcionamento. As que resistiram, tiveram que reajustar as contas, reduzir o quadro de funcionários, ou deixar acumular as dívidas na espera de uma possível retomada.

Destacamos neste contexto os denominados "empreendedores", que passam por uma fase de perdas e precisam urgentemente de auxílio para tentar sobreviver no mercado. A perda de capital por conta das medidas restritivas determinadas pelos protocolos internacionais, bem como pelos decretos estaduais e municipais, atingiu de forma mais incisiva as pequenas empresas, mais especificamente, aqueles indivíduos que precisam de apoio para honrar suas dívidas, e, de certo modo, possibilitar que a máquina ande, o capital gire.

É conhecendo as condições postas e estudando a conjuntura atual e os efeitos da crise no setor financeiro, sobretudo nas empresas privadas, que a campanha do Bradesco, por lidar com o instante, promovendo uma refração da realidade, retoma um discurso de comprometimento 
com o outro. E assim, com este teor psicanalítico num momento de tanta complexidade, o Bradesco projeta suas lentes na campanha "Aguente firme para reinventar o futuro".

Com duração de 01:00 (um minuto), o anúncio (o filme da campanha) aparece com uma série de cenas que retratam o momento atual. Selecionamos algumas:

Figuras 1, 2, 3 e 4: Campanha do Bradesco:

"Aguente firme para reinventar o futuro".

Figura 1

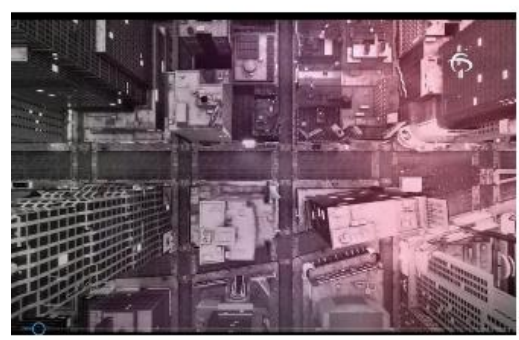

Figura 3

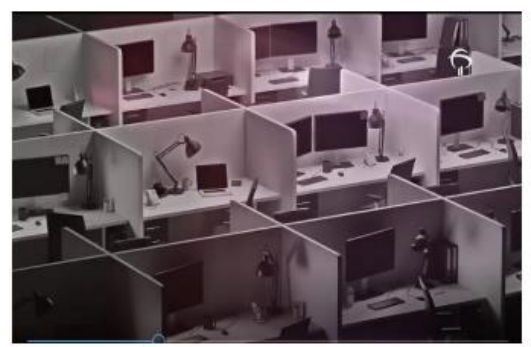

Figura 2

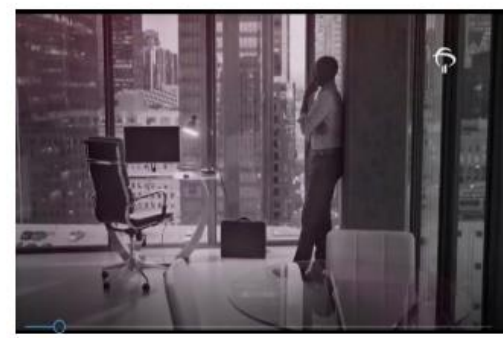

Figura 4

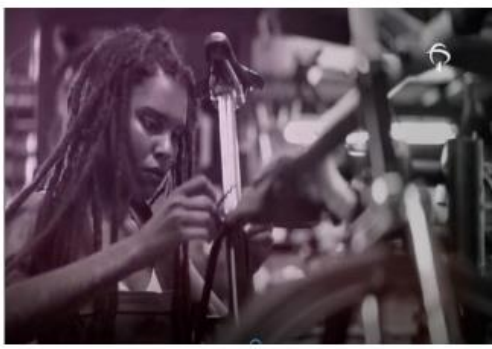

Fonte: Disponível em: https://www.youtube.com/watch?v=CIytl3hlOzs O texto da campanha vem com os seguintes enunciados:

Nunca é cedo pra abrir um negócio. Ou tarde. Parece arriscado? Ahhh! Não pra você. Quantas vezes você já ouviu que era loucura? Muitas. Quantas vezes você desistiu? Nenhuma. Empreender não é dar ouvidos pro que as pessoas dizem. Mas ouvir o que você tem a dizer pras pessoas. E nesse momento tão desafiador, o Bradesco 
também tem uma coisa pra dizer a você, empreendedor brasileiro. Aguente firme! Vamos seguir ao seu lado nos reinventando a cada dia para oferecer soluções que ajudem a suavizar o caminho do seu negócio. Pode demorar um pouquinho. Pode ser difícil. Mas vai passar. Reinvente o futuro! Bradesco. (BANCO BRADESCO S.A, 2020).

O enunciado empreendedorismo é visto na instância empresarial como a capacidade do indivíduo para investir em algo, realizar um projeto. Um sujeito empreendedor compreende aquele que se submete aos riscos e inconstâncias do mercado, mas desenvolve ações que possibilitem a geração de capital. Com estes princípios, o Bradesco retoma o discurso advindo da prática capitalista, sobretudo do regime econômico neoliberal, para se (re)afirmar como uma empresa séria que pensa em seu cliente - o empreendedor. A campanha é direcionada para os microempreendedores: pessoas que queiram abrir (ou continuar) com um negócio, mas não se sentem seguras neste momento de crise.

Aqui vale uma reflexão: A noção de empreendedorismo ressurge nesta condição de produção (discurso publicitário), de modo ainda mais incisivo no contexto pandêmico - o que comprometeu a vida financeira dos sujeitos (microempreendedores). Nossa discussão aqui incide na forma como uma empresa (agência bancária) difunde uma imagem de positividade e resiliência para vender seus produtos - aspectos característicos de uma sociedade capitalista. Entram em jogo neste entrelaçamento de dizeres outras estratégias para atingir mentes e corações dos sujeitos potenciais consumidores. Empreender, neste sentido, implica em se arriscar e ao mesmo tempo confiar que o Bradesco S.A trará a solução para um problema que apareceu de modo inesperado. Cria-se uma sensação de segurança frente aos desafios cotidianos que se intensificaram com a pandemia.

A propaganda vem predominantemente com uma imagem de opacidade, com tons em preto, branco e cinza que estão alinhadas ao clima de luto vivenciado no país. Este clima é bem aproveitado na narrativa da campanha.

A utilização de cores, que também são discursos, configura uma estratégia primordial para estabelecer efeitos de sentido. Sobre a representação das cores no discurso midiático, Guimarães (2003, p. 29) aponta que "a simples organização de informações por meio de cores 
pode também transferir significados e valores para cada grupo de informações que àquela cor foi subordinado".

Conforme as capas que funcionam como as vitrines dos meios impressos (como o jornal e a revista), a organização do dizer por meio de imagens, cores e tantos outros efeitos técnicos funcionam como mecanismos de disciplinarização dos sujeitos, sobretudo neste século XXI, um momento em que vigora uma cultura imagética que recebe primazia a palavra em movimento.

As imagens são dispositivos de memória que estão em constante atualização. Quanto aos sentidos acionados pela imagem, Courtine (2013) observa que deve haver uma mediação, a partir do fazer arqueológico amplamente utilizado por Foucault. Para tanto, Courtine elabora o conceito de intericonicidade que compreende: "Redes de reminiscências pessoais e de memórias coletivas que religam as imagens umas às outras. É deste modo que toda fotografia suscita outra, que toda imagem estende ramificações genealógicas na memória das imagens". (COURTINE, 2013, p. 157).

Na campanha do Bradesco as imagens são determinantes para a construção do sentido. Com uma música instrumental (som de piano) ao fundo, e um ângulo projetado para o alto dos edifícios deixando à mostra o vazio das ruas e avenidas de uma grande cidade, a campanha recupera o espírito de luta e tristeza predominante na conjuntura atual. Na sucessão de imagens, aparece um escritório sem funcionários com a presença de apenas um homem escorado em uma parede, olhando para uma janela de vidro, conforme vemos na Figura 2. As imagens se sucedem lentamente no mesmo ritmo da narrativa representada por uma voz feminina. Neste primeiro momento, deixa-se claro que não há motivo para alegria ou entusiasmo, mas há um convite para a reflexão, um exercício de introspecção conforme o andar dos acontecimentos.

Observamos que na sequência discursiva materializada no texto e reafirmada nas imagens, apresenta-se uma tentativa de estabelecer um vínculo estreito com o/a cliente empreendedor(a). As perguntas retóricas são estrategicamente utilizadas para dialogar com o sujeito empreendedor. Uma busca de aproximação que espelha os conflitos internos e incertezas do futuro. Todavia o banco se subjetiva como aquele que acolhe e acredita no potencial deste sujeito/empreendedor/cliente. Não há um convite para se arriscar num novo negócio. Há uma intimação: 
"Nunca é cedo pra abrir um negócio. Ou tarde. Parece arriscado? Ah! Não pra você. Quantas vezes você já ouviu que era loucura? Muitas. Quantas vezes você desistiu? Nenhuma. Empreender não é dar ouvidos pro que as pessoas dizem. Mas ouvir o que você tem a dizer pras pessoas". (BANCO BRADESCO S.A, 2020).

Temos nestes enunciados um discurso de responsabilidade social pautado na realidade atual. Os questionamentos são produzidos para atingir o imaginário dos sujeitos que estão em posição de inferioridade. No entanto, a fórmula encontrada para o aprofundamento desta relação/dominação é adjetivar este cliente, reafirmar seus valores e fazê-lo acreditar em seu potencial de investimento.

Há nesta estratégia uma tecnologia de poder disciplinar que controla este corpo tornando-o dócil, e, consequentemente, produtivo. Na mídia, nada é feito sem um propósito. Há um jogo psicanalítico constituído de regras para atingir este sujeito empreendedor. Assim, os traumas pelo fracasso no negócio e as inseguranças em abrir ou manter uma empresa contribuem para o caráter de vulnerabilidade do sujeito. A empresa, enquanto por ocupar um lugar de verdade e credibilidade, entende que o negócio é um terreno movediço, e que os sujeitos, considerados aqui como clivados, censurados, em constantes conflitos e crises existenciais, terão seus espaços e vencerão tais desafios.

Os dispositivos disciplinares seguem em cada enunciado, em cada imagem, ao ritmo da música que dialoga com a caótica conjuntura nacional e internacional e que podemos constatar no endereço: https://www.youtube.com/watch?v=Clytl3hlOzs\&ab_channel=brades co.

Esta relação de poder é evidenciada também nas sequências discursivas a seguir:

E nesse momento tão desafiador, o Bradesco também tem uma coisa pra dizer a você, empreendedor brasileiro. Aguente firme! Vamos seguir ao seu lado nos reinventando a cada dia para oferecer soluções que ajudem a suavizar o caminho do seu negócio. Pode demorar um 
pouquinho. Pode ser difícil. Mas vai passar. Reinvente o futuro! Bradesco. (BANCO BRADESCO S.A, 2020).

No processo de discursivização da campanha detectamos alguns elementos de similitude com o discurso religioso, mais especificamente com o poder pastoral quando a peça publicitária se propõe conduzir os clientes, os sujeitos empreendedores. O poder pastoral é discutido por Foucault, em Segurança, Território, População (2008) em que se constrói um sentido de proteção e cuidado com o próximo. Para explicar como tal poder aparece na materialidade discursiva, o teórico faz uma retrospectiva da narrativa do povo hebreu com a saída do Egito, conduzida por Moisés em busca de uma terra prometida. Para Foucault:

\begin{abstract}
O poder do pastor é um poder que não se exerce sobre um território, é um poder que, por definição, se exerce sobre um rebanho, mais exatamente sobre o rebanho em seu deslocamento, no movimento que o faz ir de um ponto a outro. $\mathrm{O}$ poder do pastor se exerce essencialmente sobre uma multiplicidade em movimento. (FOUCAULT, 2008, p.168).
\end{abstract}

Voltando para as condições postas neste discursivo fílmico da campanha, vemos que a empresa (Bradesco) assume um lugar de dominação típica de um poder pastoral com a função de conduzir esta ovelha, ou seja, o empreendedor, mostrando o caminho para sua salvação que aqui se traduz em: continuar confiando nos serviços de empréstimo e outros pacotes ofertados pelo pastor/Bradesco. Só assim, seguindo este caminho apontado pelo banco, o cliente chegará nesta "terra prometida". Para tanto, vemos um realce de palavras de efeito que ratificam o sentido de solidariedade e resiliência como uma voz imperativa:

"Aguente firme! Vamos seguir ao seu lado nos reinventando a cada dia para oferecer soluções que ajudem a suavizar o caminho do seu negócio." (BANCO BRADESCO S.A., 2020). 
Chamamos atenção para o fato de que as mídias funcionam através de narrativas que se aproximam do fazer cinematográfico. A imagem em movimento, que é um discurso, promove também movimentos de subjetividades e reafirmação de valores cristalizados ao longo do tempo. Com a proposta de inovação em reinventar outras formas de sobreviver (já que muitos foram demitidos ou viram seu negócio fracassar), o banco, de olho neste momento de fragilidade e vulnerabilidade, busca se fazer presente instaurando, assim, mecanismos disciplinares.

Os já ditos são materializados como um efeito de algo "novo" porque as formas de veiculação destes discursos passam por constantes atualizações, tendo em vista que estamos num espaço midiático. Assim, outras empresas bancárias podem também se utilizar da crise pandêmica e construir uma narrativa, mas haverá sempre a fabricação de uma realidade, ou seja, todos falam sobre o mesmo fato, mas de outros modos, com tecnologias de poder diferentes. Tais efeitos de sentido são vistos na sequência de imagens que aparecem ao longo do filme:

Figuras 5, 6, 7 e 8. Campanha do Bradesco:

Aguente firme para reinventar o futuro

Figura 5

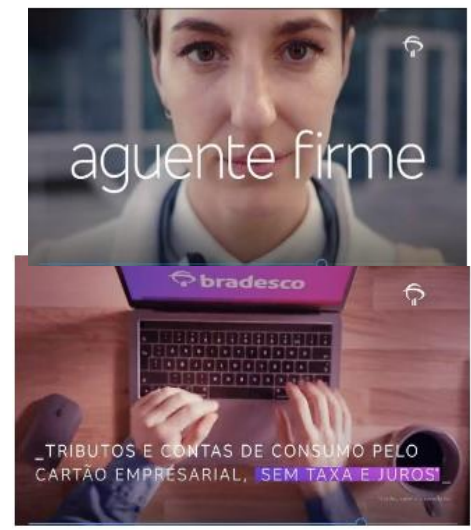

|Figura 6

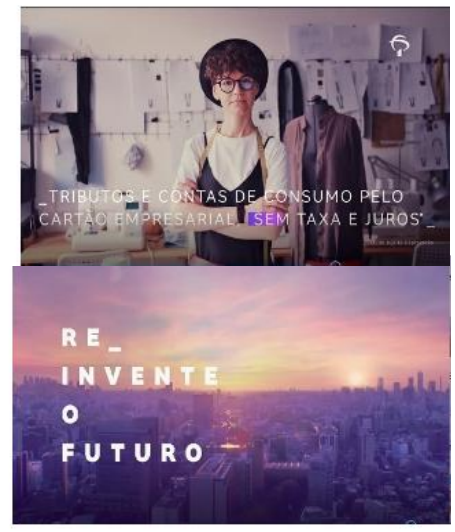

Fonte: Disponível em: https://www.youtube.com/watch?v=CIytl3hlOzs 
A música de fundo com marcações lentas que dialogam com o sentimento de melancolia ratificada nas cores, gestos, espaços vazios e voz da narradora, perduram até o segundo 40 (quarenta). A partir daí, há uma mudança significativa. Ouve-se uma pausa sincronizada com a frase "Aguente firme" e alteração do ritmo para algo mais intenso. A música instrumental entra em consonância com o olhar fixo dos sujeitos projetados para a câmera. Percebe-se que a imagem cabisbaixa e expressão corporal que revelavam dor e sofrimento predominantes nas primeiras cenas, se transforma em uma imagem de altivez e confiança quando os personagens direcionam o olhar para a frente e encaram a câmera. O diálogo entre banco e cliente, ou entre texto e leitor, se intensifica e se estabelece um maior vínculo indissociável. Neste momento se estabelece uma relação de íntima reciprocidade.

Ainda perduram o clima de luto e respeito, mas os tons cinzentos e opacos são substituídos por cores mais frias e igualmente suavizadas. A campanha indica que é preciso respeitar o momento de crise, mas já há uma perspectiva de futuro promissor. E como uma sinalização do alinhamento discursivo da campanha com as demandas atuais, sobretudo com os debates sobre diversidade e valorização identitária, temos a projeção de indivíduos de diferentes etnias, idades, bem como várias áreas profissionais. Conforme vemos nas imagens já destacadas neste artigo (figuras 4, 7 e 8 ).

A partir dos elementos detectados ao longo desta análise, demarcamos pelo menos três momentos que se coadunam na campanha do Bradesco. São eles:

$1^{\circ}$ momento: a perda de capital, o luto, e os conflitos internos que estão presentes na sonoridade e palheta de cores opacas entre o branco, o preto e o cinza que emolduram as imagens.

$2^{\circ}$ momento: A convocação para a retomada de capital, reforçada no pedido de empréstimo ao banco. Tais jogos de relações são representados na elipse do texto - um silêncio localizado e constitutivo de sentido. E ainda, no surgimento de outras cores.

$3^{\circ}$ momento: A projeção para o futuro que só será promissor se o empreendedor conseguir comprar esta ideia, ou seja, adquirir os produtos que são ofertados. Vemos nesta mudança de narrativa, o lento preenchimento dos espaços antes vazios, que agora são ocupados por sujeitos em ação, utilizando as tecnologias - o que configura a parceria, mesmo remota, entre banco e cliente. 
Chega-se, pois, à fórmula do sucesso que vem com nervuras de um discurso de renovação: este empreendedor deve reinventar seu destino, seu futuro. Para tanto, enquanto não chega a vacina que aniquile a covid-19, o Bradesco oferece um coquetel de "medicamentos" quando apresenta fórmulas que busquem ajudar na saúde financeira do empresário/cliente: "Tributos e contas de consumo pelo cartão empresarial, sem taxas de juros. Prorrogação de 60 dias em linhas de crédito. Crédito de folha de pagamento em 6 meses de carência". (BANCO BRADESCO S.A, 2020). Em cada cena, ressurgem estas medidas sempre com o destaque para os enunciados que foram selecionados como mais relevantes para o empreendedor.

A campanha "Aguente firme" compreende a primeira de uma série produzida pelo Bradesco desde o surgimento do vírus no Brasil. O banco lança um discurso com o objetivo de se mostrar partícipe nesta guerra pandêmica. É estabelecida uma relação de parceria com projeções para o futuro que está figurativizada nas tecnologias, na construção de um novo modelo econômico, e, a rigor, numa outra forma de empreendedorismo. Diante de tais elementos discursivos voltados para gerar lucro, o banco atua com mecanismos de subjetividade ao se mostrar vivo/ atuante no mercado, em detrimento de outras empresas financeiras, tanto públicas como privadas.

\section{Considerações finais}

A crise pandêmica, a maior de todos os tempos no Brasil, aprofundou o abismo social entre os brasileiros. E o setor empresarial entendeu que uma população doente não é economicamente produtiva. Assim, são necessárias estratégias para contornar os efeitos da crise. Algumas destas tecnologias de poder são utilizadas pelo discurso publicitário. Com a campanha "Aguente firme para reinventar o futuro!" o Bradesco encontra um modo disciplinar quando promove um sentido de inovação, parceria e compreensão da realidade social. $\mathrm{O}$ objetivo é buscar novos clientes, mas sem perder aqueles que o banco já conquistou.

Música, cores, formas, efeitos gráficos que dominam os enunciados em movimento, ou seja, as cenas projetadas na campanha, constituem sentido, legitimam uma credibilidade do Banco no mercado financeiro. Há uma supervalorização do cliente que é apresentado como um sujeito 
promissor, destemido, que embora passe por um momento de inseguranças, ou tentativas frustradas, conseguirá se reinventar através da "ajuda" do banco. Temos, pois, nestes jogos simbólicos, a retomada de um poder pastoral. Um mecanismo disciplinar que dociliza os corpos, tornando-os úteis, quando passa a reproduzir "verdades" defendidas pelo banco.

O discurso publicitário opera, portanto, com enunciados dispersos, ratificados e já cristalizados na sociedade. Nossa análise mostra que as imagens apresentadas nesta campanha funcionam como operadores de memória e mobilizam outros dizeres que ressurgem com efeitos de atualização. Assim, a noção de empreendedorismo é construída a partir de uma retomada da realidade social como a atenuação de conflitos e incertezas que dominam o cliente/empreendedor.

Nossa análise nos mostra que a noção de empreendedorismo aparece na opacidade do dizer envolta de outros dizeres que foram fomentados neste contexto pandêmico. De modo sutil a campanha mostra que, paradoxalmente, a crise sanitária trouxe muitas perdas de capital (sobretudo para os pequenos empresários). Mas tem gerado também lucro para empresas, sobretudo quando falamos dos bancos.

\section{Referências}

CHARAUDEAU, P. O discurso das mídias. Trad.: Angela S. M. Corrêa. Discurso das mídias. São Paulo: Contexto, 2006.

COURTINE, J.J. Decifrar o corpo: pensar com Foucault. Trad. Francisco Morás. Petrópolis, RJ: Vozes, 2013.

FOUCAULT, M. Sujeito e poder. In: DREYFUS, H. \& RABINOW, P. Michel Foucault, uma trajetória filosófica: para além do estruturalismo e da hermenêutica. Trad.: Vera Porto Carrero. Rio de Janeiro: Universitária, 1995.

FOUCAULT, M. A ordem do discurso: Aula inaugural no Collège de France, pronunciada em 2 de dezembro de 1970. Trad.: Laura Fraga de Almeida Sampaio. 6ed. São Paulo: Edições Loyola, 2000.

FOUCAULT, M. Microfísica do poder. 21 ed. Organização e Trad.: Roberto Machado. Rio de Janeiro: Edições Graal, 2005.

FOUCAULT, M. Segurança, Território, População. Trad.: Eduardo Brandão. São Paulo: Martins Fontes, 2008.

GUIMARÃES, L. As cores na mídia: a organização da cor-informação no jornalismo. São Paulo: Annablume, 2003. 
PÊCHEUX, M. Análise Automática do Discurso (AAD-69). In: GADET. Françoise e HAK, Tony. (Organizadores.) Por uma análise automática do discurso: uma introdução à obra de Michel Pêcheux. Trad.: Bethania S. Mariani (et al). 3ed. Campinas: Editora da Unicamp, 1997.

\section{Sites consultados:}

BOTERO, M. Mais de 600 mil pequenas empresas fecharam as portas com coronavírus. 2020.2 Disponível em: https://www.cnnbrasil.com.br/business/2020/04/09/mais-de-600-milpequenas-empresas-fecharam-as-portas-com-coronavirus. Acesso em: 6 de julho de 2020.

BRADESCO. Aguente firme e Reinvente o futuro. 2020. Disponível em: https://www.youtube.com/watch?v=CIytl3hlOzs. Acesso em 7 de julho de 2020.

PORTAL G1. 2020. Disponível em:

https://g1.globo.com/bemestar/coronavirus/noticia/2020/08/19/casos-

e-mortes-por-coronavirus-no-brasil-em-19-de-agosto-segundo-

consorcio-de-veiculos-de-imprensa.ghtml

ROSA, Bruno. Propaganda do azeite Gallo está na mira do Conar. 2012. Disponível em: https://oglobo.globo.com/economia/propaganda-doazeite-gallo-esta-na-mira-do-conar-4106382. Acesso em 10 de agosto de 2020 .

\section{Notas}

* Doutora em Letras pela Universidade Federal da Paraíba (UFPB). Professora do Departamento de Língua Portuguesa e Linguística (DLPL) da Universidade Federal da Paraíba (UFPB), Campus I.

${ }^{1}$ Dados do consórcio de imprensa. Disponível em: https://g1.globo.com/bemestar/coronavirus/noticia/2020/08/19/casos-e-mortes-porcoronavirus-no-brasil-em-19-de-agosto-segundo-consorcio-de-veiculos-deimprensa.ghtml

${ }^{2}$ Disponível em: https://www.cnnbrasil.com.br/business/2020/04/09/mais-de-600-milpequenas-empresas-fecharam-as-portas-com-coronavirus

${ }^{3} \mathrm{Em} 2012$, a marca Gallo foi obrigada a retirar do ar uma peça que segundo o CONAR trazia um discurso racista. Com o slogan "O nosso azeite é rico. O vidro escuro é o segurança. Disponível em: https://oglobo.globo.com/economia/propaganda-do-azeitegallo-esta-na-mira-do-conar-4106382. 
${ }^{4}$ Disponível em: https://www.youtube.com/watch?v=CIytl3hlOzs

${ }^{5}$ Disponível em: https://www.msn.com/pt-br/noticias/mundo/efeitos-da-pandemia-na$\underline{\text { sa\%c3\%bade-mental/vi-BB1871AS }}$ 